\title{
Atmospheric hydrogen variations and traffic emissions at an urban site in Finland
}

\author{
T. Aalto, M. Lallo, J. Hatakka, and T. Laurila \\ Finnish Meteorological Institute, Climate Change Research, P.O. Box 503, 00101 Helsinki, Finland \\ Received: 18 May 2009 - Published in Atmos. Chem. Phys. Discuss.: 25 June 2009 \\ Revised: 1 September 2009 - Accepted: 8 September 2009 - Published: 5 October 2009
}

\begin{abstract}
Atmospheric hydrogen $\left(\mathrm{H}_{2}\right)$ mixing ratios were observed over a one year period from summer 2007 to 2008 in Helsinki, Finland. Relatively stable background values of hydrogen were occasionally observed at the site, with minimum in October and maximum between March and May. High hydrogen mixing ratios occurred simultaneously with high carbon monoxide $(\mathrm{CO})$ values and coincided with high traffic flow periods. Carbon monoxide and radon $\left({ }^{222} \mathrm{Rn}\right)$ were continuously monitored at the same site and they were used in estimation of the hydrogen emissions from traffic. The morning rush hour slope of $\Delta \mathrm{H}_{2} / \Delta \mathrm{CO}$ was in average $0.43 \pm 0.03 \mathrm{ppb}\left(\mathrm{H}_{2}\right) / \mathrm{ppb}(\mathrm{CO})$. After correction due to soil deposition of $\mathrm{H}_{2}$ the slope was $0.49 \pm 0.07 \mathrm{ppb}\left(\mathrm{H}_{2}\right) / \mathrm{ppb}(\mathrm{CO})$. Using this slope and $\mathrm{CO}$ emission statistics, a road traffic emission of about $260 \mathrm{t}$ $\left(\mathrm{H}_{2}\right) /$ year was estimated for Helsinki in 2007.
\end{abstract}

\section{Introduction}

Hydrogen as an energy carrier has been under discussion during recent years (e.g. Prather, 2003; Service, 2004; Jacobson, 2005). The impact of hydrogen economy on the global climate has been studied e.g. by Schultz et al., 2003; Tromp et al., 2003; Derwent et al., 2006; Jacobson, 2008. Adoption of hydrogen economy could mean increased hydrogen emissions (Tromp et al., 2003; Schultz et al., 2003; Warwick, 2004). Hydrogen emissions are not without problems, since its role as an indirect greenhouse gas (IPCC, 2007). On the other hand, using hydrogen instead of fossil fuels would decrease emissions of $\mathrm{NO}_{\mathrm{x}}$ etc. (Schultz et al., 2003), and thus

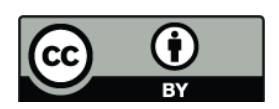

Correspondence to: T. Aalto (tuula.aalto@fmi.fi) might in total act towards less enhanced greenhouse effect. The use of hydrogen technology is, however, at its infancy (Prather, 2003; Service, 2004).

Hydrogen mixing ratios have been measured during past years at background and urban sites (Novelli et al., 1999; Simmonds et al., 2000; Barnes et al., 2003; Steinbacher et al., 2007; Vollmer et al., 2007; Yver et al., 2009). The annual mean hydrogen background is lower in the Northern Hemisphere than in the Southern Hemisphere, and the northernmost continental sites have the largest annual cycles (Novelli et al., 1999). Variations in the observed mixing ratio are due to different removal mechanisms in addition to changes in emissions. The chemical removal of hydrogen from tropospheric air occurs through reaction with $\mathrm{OH}$ radical. Thus, hydrogen is indirectly affected by numerous air chemical cycles. Soil deposition is even more important removal route, the mechanism and extent of which is due to large uncertainties (e.g. Smith-Downey et al., 2006; Xiao et al., 2007; Lallo et al., 2008; Schmitt et al., 2008). The difference between Southern and Northern Hemisphere hydrogen levels has been attributed to asymmetry of soil uptake, because the majority of global land area is located in Northern Hemisphere (Novelli et al., 1999). The low annual autumn - early winter minimum in northern continental high latitudes is also due to dominance of the soil sink together with weakening of the photochemical sources and formation of a stable boundary layer which prevents vertical mixing (Price et al., 2007). However, the soil sink weakens in persistent freezing temperatures when soil freezes and snow cover becomes thick hindering diffusion (Lallo et al., 2008).

The most important sources of hydrogen include photochemical methane and other hydrocarbon (mainly isoprene) oxidation, biomass burning and combustion from technological processes (e.g. Novelli et al., 1999; Rhee et al., 2006; Ehhalt and Rohrer, 2009). The influences of the hydrogen

Published by Copernicus Publications on behalf of the European Geosciences Union. 
source from fuel combustion are largest in the Northern Hemisphere and can be seen as high short-term variability in the continuous urban hydrogen observations (e.g. Steinbacher et al., 2007; Yver et al., 2009). Urban emissions of hydrogen, such as sources from traffic-related combustion processes, can be estimated by using simultaneous observations of $\mathrm{CO}$, whose sources are similar and emission inventories are well established. The $\Delta \mathrm{H}_{2} / \Delta \mathrm{CO}$ slopes have been observed at relatively polluted and unpolluted sites (Simmonds et al., 2000; Barnes et al., 2003; Steinbacher et al., 2007; Hammer et al., 2009) as well as in a traffic tunnel (Vollmer et al., 2007). The value of the slope depends on e.g. the vehicle types, chemical transformation, and deposition on the way to the measurement site. This makes the slope dependent on the local emission structure and environmental conditions. The value of the slope may be influenced by the seasonal variation of the meteorological conditions. During the high northern latitude winter the photochemical reactions and vertical mixing are suppressed, while in summer the radiation may enhance vertical mixing and photochemical reactions already before the morning rush hour.

Urban studies are important for studying emissions and trends in atmospheric hydrogen. They also help in closing the current hydrogen budget. In this article we present the variation of atmospheric hydrogen in Helsinki and calculate emissions using the $\Delta \mathrm{H}_{2} / \Delta \mathrm{CO}$ slope, and estimate the role of soil deposition in the daily hydrogen dynamics. The soil deposition rates in Helsinki are estimated in a companion article (Lallo et al., 2009).

\section{Materials and methods}

\subsection{Measurement site}

Helsinki is located in southern Finland at the coast of the Baltic Sea. Population of Helsinki is about 568000 (year 2007). The measurement site $\left(60^{\circ} 12^{\prime} 13^{\prime \prime} \mathrm{N}, 24^{\circ} 57^{\prime} 40^{\prime \prime} \mathrm{E}\right.$, $53 \mathrm{~m}$ a.s.1.) is located at about $6 \mathrm{~km}$ distance from the city center in Kumpula campus area (Fig. 1). The nearby area is occupied mainly by university, residential and commercial buildings. The shortest distance from the site to the Baltic Sea coast is about one kilometer.

The sampling inlet was on the roof of the Finnish Meteorological Institute's (FMI) building at about $25 \mathrm{~m}$ above the ground. The wind parameters were measured at a $32 \mathrm{~m}$ high mast next to the building and temperature at $2.5 \mathrm{~m}$ above the ground. The building is located on a top of a hill about $15 \mathrm{~m}$ above the nearest major Hämeentie road (Fig. 1). In autumn 2007, the traffic volumes at Hämeentie and Mäkeläntie roads typically exceeded 40000 cars in a workday (Helsinki city traffic office, 2008). The amount of traffic varies considerably being lowest during holidays (July, weekends and nights). The lowest monthly mean temperature during the

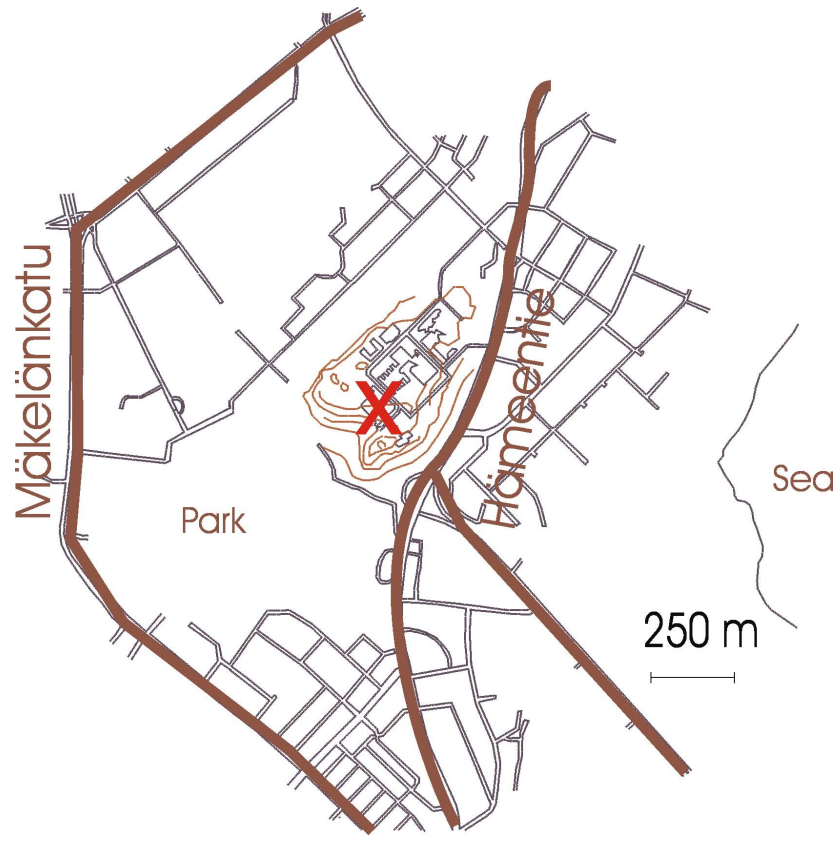

Fig. 1. Location of the sampling site in Kumpula, Helsinki. Thick lines are major roads. The minimum distance from the Hämeenkatu road to the sampling site is $250 \mathrm{~m}$. Distance to Mäkelänkatu is $860 \mathrm{~m}$.

one-year long measurement period was $0.0^{\circ} \mathrm{C}$ in March 2008 and highest $17.8^{\circ} \mathrm{C}$ in August 2007 .

\subsection{Instrumentation}

$\mathrm{H}_{2}$ and $\mathrm{CO}$ were monitored using an automated gas chromatographic system based on Trace Analytical RGA5 equipped with a Reduction Gas Detector. The instrument relies on a detection principle first introduced by Schmidt and Seiler (1971). Reducing gas, in this case molecular hydrogen or carbon monoxide, reduces $\mathrm{HgO}$ and the emerging $\mathrm{Hg}$ vapor is detected by UV absorption. The instrument has Unibeads $1 \mathrm{~S}(1 / 8 \mathrm{in} . \times 31 \mathrm{in}$; $0.318 \mathrm{~cm} \mathrm{OD} \times 79 \mathrm{~cm})$ precolumn, and Molecular Sieve 5A $(1 / 8 \mathrm{in} . \times 31 \mathrm{in}$; $0.318 \mathrm{~cm} \mathrm{OD} \times 79 \mathrm{~cm})$ analytical column. The columns were maintained at $100^{\circ} \mathrm{C}$, and carrier gas was synthetic air. Total measurement time for a sample was $300 \mathrm{~s}$. After every three ambient air samples one working standard gas sample were measured. Sample air was taken as a side flow from a high flow stream (used by the radon instrument), using a PTFE diaphragm pump. This stream was lead to a pressure relief valve, which was adjusted to pass about $200 \mathrm{ml} / \mathrm{min}$ through the sample loop.

Continuous CO observations by YTV Helsinki Metropoli$\tan$ Area Council at two urban sites were also used in this paper. The CO measurement was based on absorption of infrared radiation. The instrument (Horiba APMA 360) was regularly calibrated for a $0-16 \mathrm{ppm}$ mixing ratio range, created by dilution from a $150 \mathrm{ppm}$ cylinder. 
The radioactive radon isotope ${ }^{222} \mathrm{Rn}$ was measured at the Kumpula site with FMI's radon instrument. The system is based on the method, where aerosols are collected continuously onto a filter and its total beta activity is measured. The hourly mean values were calculated by assuming that the beta activity on the filter is only from short-lived radon $\left({ }^{222} \mathrm{Rn}\right)$ progeny in equilibrium with it (Paatero et al., 1998).

The weather parameters were monitored with an automated weather station MILOS 500. Wind parameters were measured with a two component ultrasonic anemometer and temperature with a shielded Pt100 detector. Visibility was measured with a Vaisala FD12 visibility meter, based on forward-scatter sensor.

\subsection{Linearity, reproducibility and calibration checks}

The RGA5 instrument's response was studied against a range of mixing ratios created from a high concentration (103 ppm $\mathrm{H}_{2}$ in synthetic air, Messer, Air Liquide) reference gas using a gas blender (Peak Laboratories Peak Span Gas Blender). First and higher order polynomials were fitted to the measurement series of concentration vs. sample peak area resulting in $R^{2}$ of over 0.99 (the average standard deviation $\sim 3.5 \%$ ) over the atmospheric range (400-700 ppb). Use of higher order polynomials did not improve $R^{2}$ suggesting that the response of the instrument was linear, and no nonlinearity correction was applied. Reproducibility was estimated using 10-40 consecutive working standard samples. The standard deviation of the resulting values was $1.1 \%$.

The measurement results were calculated using ratio of sample peak area to peak area of calibrated working standard gas. Four primary hydrogen calibration gas cylinders were used to calibrate the working standard. These standards (range 400-700 ppb) were acquired from Max-Planck Institute in Jena, Germany, and were in MPI2009 scale (revised in March 2009, see also Jordan, 2006). Three NOAA/ESRL standards (range 70-250 ppb) were used for carbon monoxide. No drift was observed in the working standard during the measurement period.

Helsinki RGA5 results were compared to other $\mathrm{H}_{2}$ analyses. Sample glass flasks were filled on the Helsinki institute's roof $\left(\mathrm{H}_{2}\right.$ mixing ratio near $\left.500 \mathrm{ppb}\right)$ and analysed with RGA5. Online measurements made with RGA5 during the flask filling period were in close agreement with the flask results, indicating that there was no loss or production of $\mathrm{H}_{2}$ in the sampling lines. Flasks were also analysed with an independent Pallas $\mathrm{H}_{2}$ system (Peak Performer GC), showing less than 5 ppb difference to Helsinki results. Pallas and Helsinki $\mathrm{H}_{2}$ analyses were also in good agreement with intercomparison performed by European hydrogen monitoring laboratories.

\subsection{Analysis of the results}

The calculation of mixing ratios from the RGA5 results were made using Matlab®, as well as the figures and mathematical analyses concerning slope and emission calculations. Hydrogen emissions can be estimated from the simultaneous increase in hydrogen and carbon monoxide mixing ratios, if $\mathrm{CO}$ emissions are known:

$\frac{j_{\mathrm{H}_{2}}^{\mathrm{emi}}}{j_{\mathrm{CO}}^{\mathrm{emi}}}=\frac{\Delta \mathrm{H}_{2}}{\Delta \mathrm{CO}}$,

where $j_{\mathrm{H}_{2}}^{\text {emi }}$ and $j_{\mathrm{CO}}^{\text {emi }}$ are the emissions of $\mathrm{H}_{2}$ and $\mathrm{CO}$, respectively, and $\Delta \mathrm{H}_{2}$ and $\Delta \mathrm{CO}$ are changes in the hydrogen and carbon monoxide mixing ratios.

According to recent findings by Hammer et al. (2009), the $\Delta \mathrm{H}_{2} / \Delta \mathrm{CO}$ slope in Eq. (1) should be corrected due to soil deposition of $\mathrm{H}_{2}$, which is a significant factor in total $\mathrm{H}_{2}$ budget. The emission ratio can be reformulated as

$\frac{j_{\mathrm{H}_{2}}^{\text {emi }}}{j_{\mathrm{CO}}^{\text {emi }}}=\frac{\Delta \mathrm{H}_{2}}{\Delta \mathrm{CO}}+\frac{j_{\mathrm{H}_{2}}^{\text {soil }}}{j_{\mathrm{CO}}^{\text {emi }}}$,

where

$j_{\mathrm{CO}}^{\mathrm{emi}}=\frac{\Delta \mathrm{CO}}{\Delta \mathrm{Rn}} C j_{\mathrm{Rn}}$.

$j_{\mathrm{H}_{2}}^{\text {soil }}$ is the hydrogen soil sink and $j_{\mathrm{CO}}^{\text {emi }}$ can be estimated e.g. with the help of the radon tracer method (Schmidt et al., 2001) by using the observed radon activity and soil exhalation rate of radon $\left(j_{\mathrm{Rn}}\right)$, estimated from local measurements (see Lallo et al., 2009). $C$ is a correction factor for radioactive decay, which can be approximated with a constant value 0.965 (Schmidt et al., 2001).

In the current work we examined the variation in mixing ratios created mainly by anthropogenic emissions. Therefore mixing ratios are often expressed as differences to the background levels, i.e. "excess mixing ratios". Background was defined as monthly means of selected data. Selection procedure excluded hourly means observed during weak mixing conditions when wind speed was lower than $3 \mathrm{~m} / \mathrm{s}$ and radon activity $>2 \mathrm{~Bq} \mathrm{~m}^{-3}$. Hourly means that were further than two standard deviations away from a harmonic function fitted to all data were also excluded, as well as cases when air masses came from the sector between $40-190^{\circ}$ (degrees clockwise from north) and observations between 06:00 and 20:00 considered to be influenced by local traffic. All time values are given in local time (LT), which is UTC $+2 \mathrm{~h}$ in winter and $\mathrm{UTC}+3 \mathrm{~h}$ in summer.

\section{Results}

\subsection{Annual variation}

$\mathrm{H}_{2}$ and $\mathrm{CO}$ were monitored in Helsinki from June 2007 to July 2008. Emissions from close by sources were clearly 


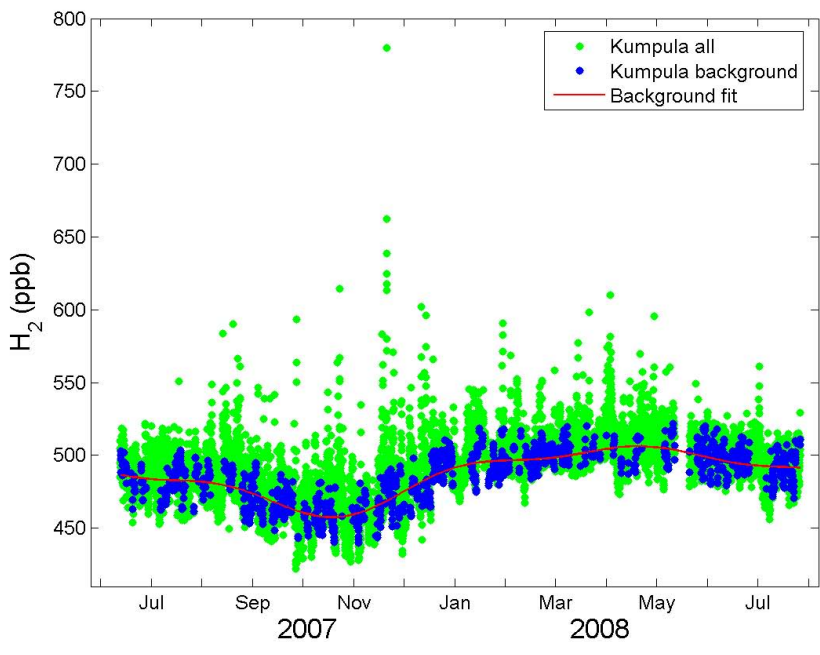

Fig. 2. Hydrogen mixing ratios at Kumpula site in Helsinki. All refers to all hourly mean values and background to selected hourly values. Red line is the harmonic fit to the background data.

distinguishable (Fig. 2). Roughly 5 to 10 simultaneous $\mathrm{H}_{2}$ and $\mathrm{CO}$ episodes were observed in a month, occurring most likely during workdays outside summer holiday season. The episodes lasted for few hours. Background values with relatively stable mixing ratios of $\mathrm{H}_{2}$ were also frequently observed at the site. This is due to the inlet elevation of about $40 \mathrm{~m}$ and distance of more than $200 \mathrm{~m}$ from the nearest major road. The lowest mixing ratios observed during nocturnal low wind speed and high radon activity conditions may indicate $\mathrm{H}_{2}$ soil deposition. The background minimum $\mathrm{H}_{2}$ mixing ratios were observed in October and maximum from March to May. $\mathrm{H}_{2}$ background levels were rather low, but in general agreement with northern results by e.g. Price et al. (2007). Price et al. (2007, Fig. 4 therein) estimates roughly $500-520 \mathrm{ppb}$ for Helsinki latitude during MarchMay, while our result was $503 \mathrm{ppb}$ and $450-475 \mathrm{ppb}$ for September-November (465 ppb).

$\mathrm{CO}$ experienced more short term variation than $\mathrm{H}_{2}$ in Kumpula (Fig. 3). However, the $\mathrm{CO}$ record at $5 \mathrm{~m}$ distance from a heavy traffic road Mannerheimintie in the city center showed considerably higher values, as well as the Leppävaara site further away from the city (data provided by YTV Helsinki Metropolitan Area Council). The lower $\mathrm{CO}$ envelopes at these three sites were in very good agreement showing similar long term variation due to synoptic changes in air mass transport and annual cycle of $\mathrm{CO}$. The background minimum $\mathrm{CO}$ mixing ratios were observed from July to September and maximum from March to April at Kumpula.

The wind direction readings at the site were most often between $180^{\circ}-240^{\circ}$, corresponding to air mass arrivals from southwest. High $\mathrm{CO}$ emissions were observed from wind sectors $150^{\circ}-190^{\circ}$ and $40^{\circ}-90^{\circ}$ (Fig. 4), indicating emis-

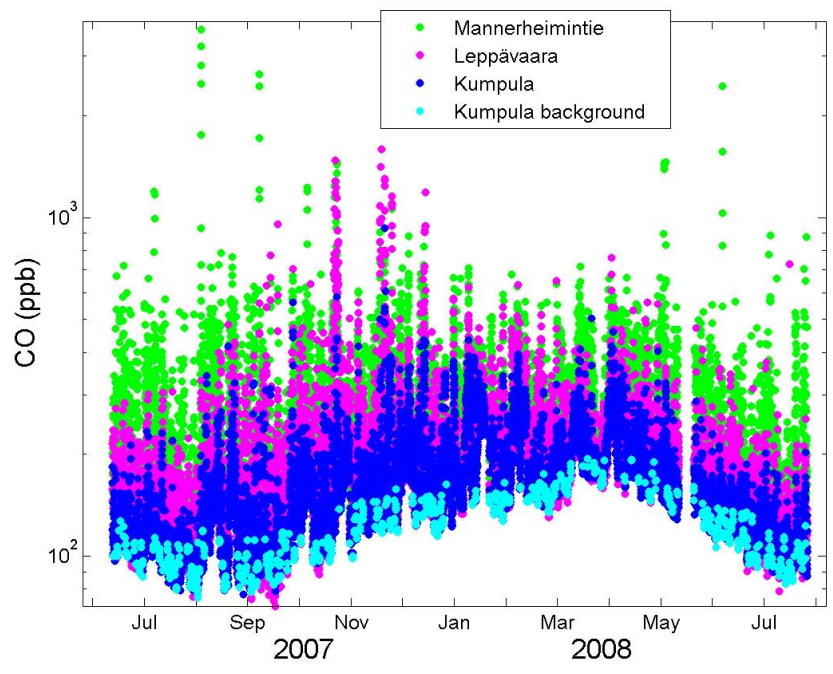

Fig. 3. Hourly means of carbon monoxide mixing ratios at three sites in Helsinki region. Kumpula background refers to selected hourly values. Mannerheimintie and Leppävaara data provided by YTV Helsinki Metropolitan Area Council.
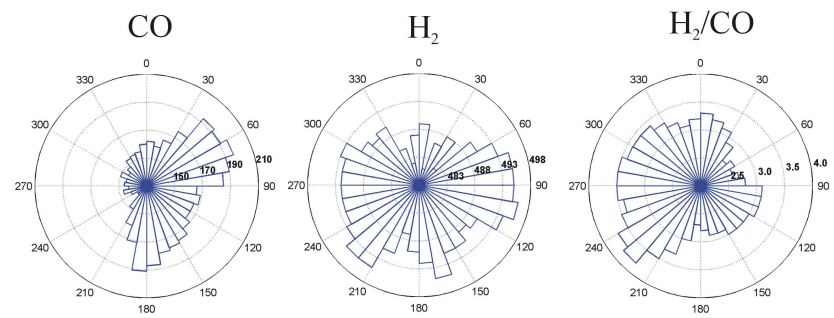

Fig. 4. Hydrogen and carbon monoxide in air masses arriving from the direction indicated by the 360 degree circle. 0 refers to winds arriving from north, and 90 east. The length of each 10 degree sector wedge is indicated by the numerical values inside the circle, either in $\mathrm{ppb}$ for $\mathrm{CO}$ and $\mathrm{H}_{2}$ or in $\mathrm{ppb}\left(\mathrm{H}_{2}\right) / \mathrm{ppb}(\mathrm{CO})$ for $\mathrm{H}_{2} / \mathrm{CO}$. The value refers to the mean mixing ratio (or $\mathrm{H}_{2} / \mathrm{CO}$ ratio) in current sector during June 2007-July 2008.

sions from the major Hämeentie road close by. According to local micrometeorological $\mathrm{CO}_{2}$ flux observations, $40^{\circ}$ $180^{\circ}$ was also defined as the sector influenced by road traffic (Vesala et al., 2008).

$\mathrm{H}_{2}$ mixing ratios were more evenly distributed among the wind sectors and the difference between high and low concentrations was smaller than in CO (Fig. 4). High mixing ratios were observed when air masses were transported from the sector between $60^{\circ}-300^{\circ}$, with maximum in $210^{\circ}-240^{\circ}$. The high mixing ratio sectors coinciding with those of $\mathrm{CO}$ may indicate influences from traffic sources close by, but the notable difference with $\mathrm{CO}$ in southwest sectors may refer to different source/sink patterns. This may indicate a notable contribution from the long range transport, because the distant emission sources are mainly located in the south - southwest along the major wind direction. The traffic intensities 
in Europe are higher than in Finland, and the lifetime of $\mathrm{H}_{2}$ is longer than that of $\mathrm{CO}$ supporting long range transport. A hydrogen sink may also draw concentrations down. Soil deposition may contribute more significantly in air masses arriving from north, where they are transported over the continent before arrival to the site.

The ratio of $\mathrm{H}_{2}$ to $\mathrm{CO}$ varied only little $(<30 \%)$ among the wind sectors, being largest during westerly winds (Fig. 4). Variation in $\mathrm{H}_{2}$ was modest in comparison to $\mathrm{CO}$. Therefore the high $\mathrm{CO}$ in the most heavily traffic-influenced wind sectors resulted in relatively low $\mathrm{H}_{2} / \mathrm{CO}$ ratio in those directions.

\subsection{Diurnal variation}

\subsubsection{Seasonal differences}

$\mathrm{H}_{2}$ and $\mathrm{CO}$ mixing ratios varied significantly over the course of a day in Helsinki (Figs. 5 and 6). In summer the diurnal variation of $\mathrm{CO}$ was quite modest, while in $\mathrm{H}_{2}$ there was an increase in mixing ratios towards afternoon hours and decrease during night. In winter a similar diurnal cycle was observed in $\mathrm{H}_{2}$ and $\mathrm{CO}$, but with a stronger increase towards afternoon. During fall and spring there was a distinct morning maximum with decrease in midday and increase again in the afternoon.

The diurnal variations are caused by the complex interplay of emissions, loss rates, transport and meteorological conditions. The traffic flow and corresponding emissions were smallest during summer (July). In winter the traffic flow was higher and more confined to rush hours in the morning and afternoon (Helsinki city traffic office, 2008). Of the sink processes, hydrogen loss through photochemical $\mathrm{OH}$ reaction is most efficient during daytime and summer (e.g. Novelli et al., 1999), while soil deposition is active throughout the day and year, if there is no flooding or permanent snow cover and temperatures are above zero (Lallo et al., 2008). The elevated mixing ratios of hydrogen and carbon monoxide in the morning may also be related to the boundary layer dynamics. The sampling site was often inside the night time stable boundary layer, since high radon mixing ratios were often observed in the early morning hours during spring, summer and autumn. Radon and other trace gas emissions may be captured in the shallow nocturnal layer, and after sunrise diluted into a larger air volume along with formation of daytime mixing layer. The highest $\mathrm{H}_{2}$ and $\mathrm{CO}$ mixing ratios did not always coincide with radon peaks, though. The sun rises in Helsinki in June already at about 04:00 and in December after 09:00 while the rush hour occurs at about 06:00-09:00. The weak wintertime boundary layer development may partly explain the December-January diurnal cycle (Figs. 5 and 6), which showed no drawdown in midday. In comparison to autumn, the winter increase in mean hydrogen and $\mathrm{CO}$ mixing ratios was modest during morning rush hour. The radon activity was low in average and showed no diurnal cycle contrary to autumn. It is possible, that the winter morning emissions

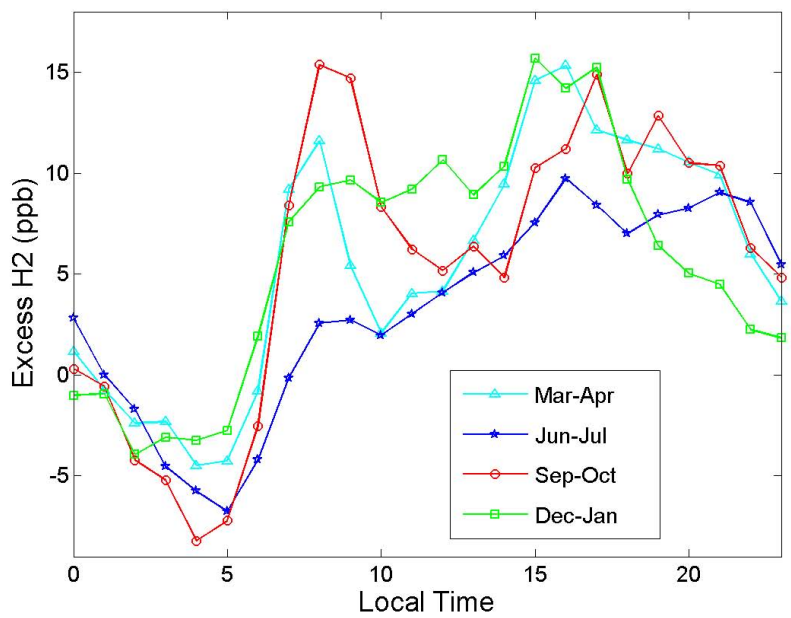

Fig. 5. Diurnal variation of excess hydrogen mixing ratios at Kumpula site in Helsinki during the four seasons in 2007-2008. The record is a combination of workday and weekend data.

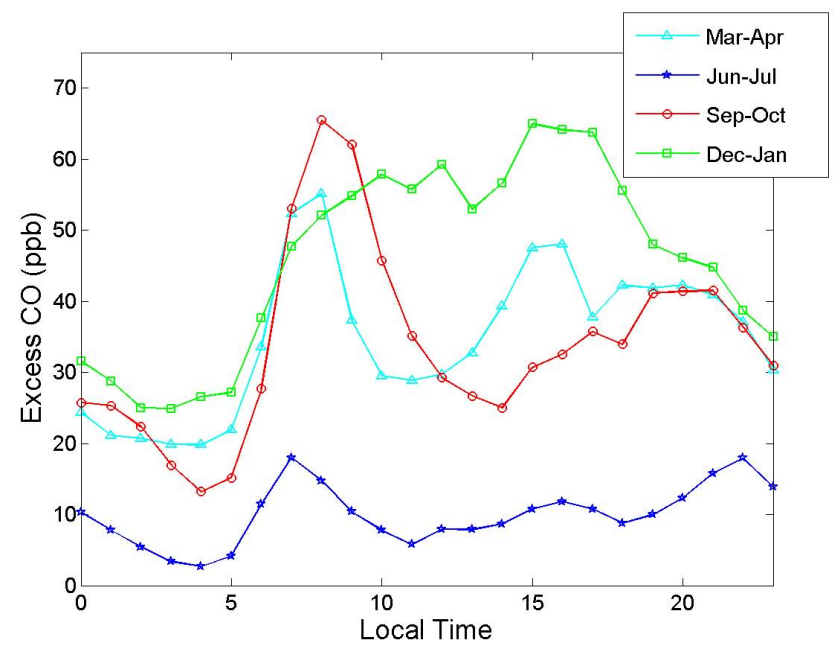

Fig. 6. Diurnal variation of excess carbon monoxide mixing ratios at Kumpula site in Helsinki during the four seasons in 2007-2008. The record is a combination of workday and weekend data.

were frequently trapped under temperature inversion below the inlet height, resulting in observations of more aged air masses obscuring the hour-to-hour variation.

\subsubsection{Rush hour $\mathrm{H}_{2} / \mathrm{CO}$ slopes}

The diurnal cycles of $\mathrm{H}_{2}$ and $\mathrm{CO}$ were very different in weekends and workdays (Fig. 7). During workdays there was a significant increase in mixing ratios during early morning hours with maximum at 08:00-09:00 The September 2007 mean traffic densities in Helsinki were similarly peaked during the workday morning hours (Helsinki city traffic office, 2008). As over $90 \%$ of CO emissions come from passenger cars in Helsinki (Niemi et al., 2008), we can therefore assume 

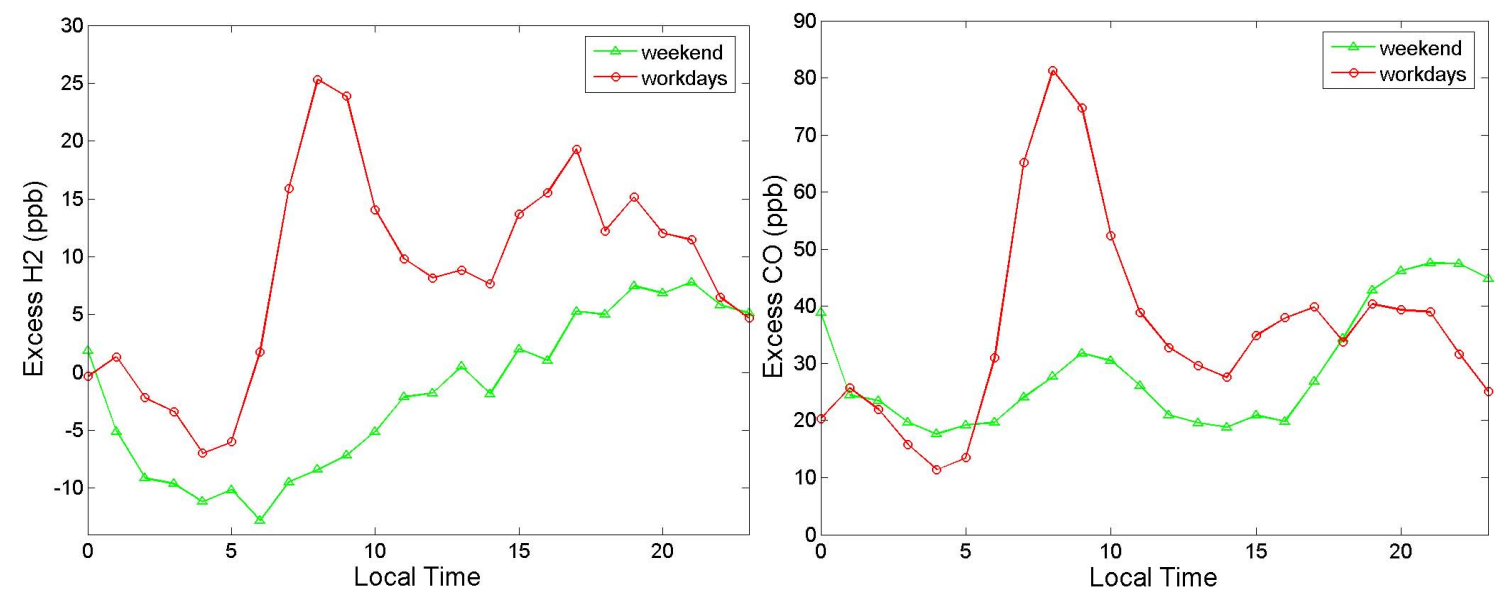

Fig. 7. Diurnal variation of excess hydrogen (a) and carbon monoxide (b) mixing ratios during workdays and weekends in SeptemberOctober 2007.

that the morning increase in $\mathrm{CO}$ and $\mathrm{H}_{2}$ is mainly caused by traffic.

The mean slope of $\Delta \mathrm{H}_{2} / \Delta \mathrm{CO}$ was calculated from the increase in $\mathrm{H}_{2}$ and $\mathrm{CO}$ mixing ratios during morning hours (LT 05:00-08:00). Individual episodes were hand-picked from the data resulting in 81 events, mainly occurring during fall, winter and spring. The slope derived by geometric functional regression was calculated for each episode with a squared correlation coefficient $\left(R^{2}\right)>0.8$ and uncertainty of the slope $<0.09 \mathrm{ppb}\left(\mathrm{H}_{2}\right) / \mathrm{ppb}(\mathrm{CO})$. The mean of all slopes was $0.43 \pm 0.03 \mathrm{ppb}\left(\mathrm{H}_{2}\right) / \mathrm{ppb}(\mathrm{CO})$. The uncertainty is given by the fitting procedure. Instrumental reasons (reproducilibility, non-linearity) might cause an additional uncertainty of max. $0.01 \mathrm{ppb}\left(\mathrm{H}_{2}\right) / \mathrm{ppb}(\mathrm{CO})$. At this point the value of the slope was not corrected due to influence by soil deposition. For comparison, workday morning data presented in Figs. 5 and 6 were used in calculations. The data represent an average from all September-October measurements, not just episodes. During the morning hours from 05:00 to 08:00 the slope was $0.44 \pm 0.02 \mathrm{ppb}\left(\mathrm{H}_{2}\right) / \mathrm{ppb}(\mathrm{CO})$, which is close to the previous estimate. At this time of the year, radon activity typically started to decrease after 08:00, suggesting that the slope represents stable nighttime conditions. The individual slopes were typically higher in summer $\left(\sim 0.5 \mathrm{ppb}\left(\mathrm{H}_{2}\right) / \mathrm{ppb}(\mathrm{CO})\right)$ than in winter $\left(\sim 0.35 \mathrm{ppb}\left(\mathrm{H}_{2}\right) / \mathrm{ppb}(\mathrm{CO})\right)$, see Fig. 8. The winter slopes had no clear connection to observed radon levels, which showed no daytime decrease either. The summer slopes were rather variable and the scatter in hourly values was larger than in other seasons, probably due to reduced traffic and thermal convection causing efficient atmospheric mixing already early in the morning.

\subsection{Individual episodes}

Large short term variation in $\mathrm{H}_{2}$ and $\mathrm{CO}$ mixing ratios in Kumpula was most probably caused by local emissions, but during some synoptic conditions the background was also elevated suggesting long range transport. Local weather also had an effect on the intensity and length of individual episodes. Generally, high mixing ratios were found on calm conditions (often together with fog formation). For example, during 27 September 2007 the Hämeentie traffic count showed the start of morning traffic at 6 (Fig. 9). Wind speed was very low with fog lowering the visibility, and radon was highly elevated indicating weak atmospheric mixing. After a small delay and further increase in radon, $\mathrm{H}_{2}$ and $\mathrm{CO}$ mixing ratios increased simultaneously. Traffic count stayed at high level until late evening, but $\mathrm{H}_{2}$ and $\mathrm{CO}$ decreased already before midday. Wind speed stayed low and radon activity high until midday, but the wind direction changed from Hämeentie to the more unpolluted north sector at the same time when $\mathrm{H}_{2}$ and $\mathrm{CO}$ started to decrease. There also was the midday downswing in the traffic count between the rush hours, but here the meteorological conditions clearly dominated the development of observed mixing ratios.

An exceptionally high episode was observed in the evening of 20 November 2007 with $\mathrm{H}_{2}$ over $750 \mathrm{ppb}$ and $\mathrm{CO}$ over $900 \mathrm{ppb}$ (Figs. 2 and 3). The slope of the event was $0.40 \pm 0.01 \mathrm{ppb}\left(\mathrm{H}_{2}\right) / \mathrm{ppb}(\mathrm{CO})$. Wind speed was rather low, around $2 \mathrm{~m} / \mathrm{s}$ and radon close to $3 \mathrm{~Bq} / \mathrm{m}^{3}$, somewhat, but not exceptionally elevated. Traffic count was not available for Hämeentie at that time, but supposedly the return traffic was already finishing. Prevailing winds changed to southwest a couple of hours before the episode maximum at 20:00 and backward trajectories showed air mass transport at altitudes $<1000 \mathrm{~m}$ along the westward coastline during the past days. The other measuring sites also indicated elevated $\mathrm{CO}$ (Fig. 3). It is therefore tempting to suggest that at least 


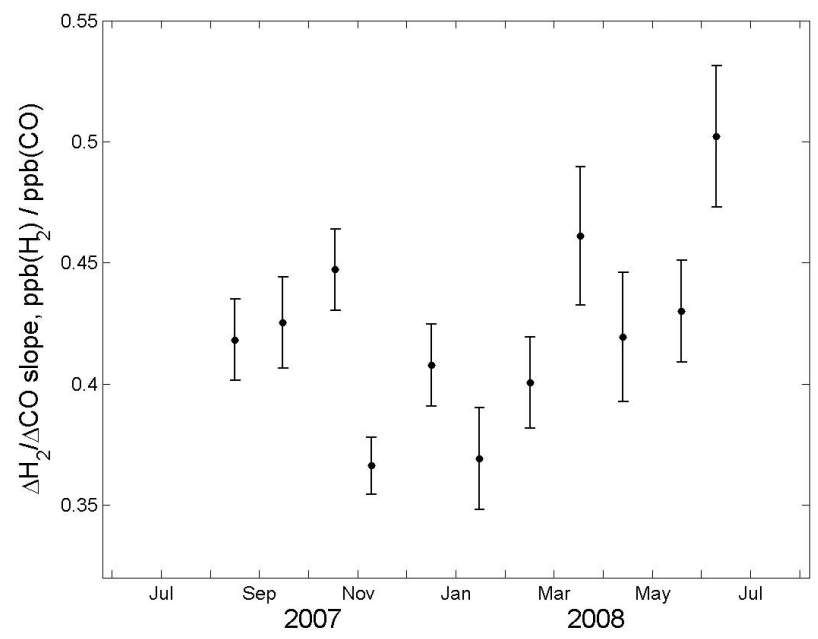

Fig. 8. Monthly variation of mean of $\Delta \mathrm{H}_{2} / \Delta \mathrm{CO}$ slopes at Kumpula site in Helsinki.

part of the increase in mixing ratios could be due to distant sources, though the rate of increase was so fast that it could have occurred due to more local sources, supported by the preceding low wind speeds and air mass transport close to ground. Helsinki was the largest town in the studied 5-day air mass path, but the lifetime of $\mathrm{CO}$ is of the order of few months, and thus long-range transport from other Finnish or European sources is possible.

\subsection{Emission and deposition rates}

\subsubsection{Carbon monoxide emissions}

Total CO emissions from Finland were $484570 \mathrm{t}(\mathrm{CO}) / \mathrm{yr}$ and from Helsinki 8888 t (CO)/yr in 2007 (Niemi et al., 2008; Statistics Finland, 2009). More than $90 \%$ of CO emissions were in Helsinki originated from road traffic, the rest being due to air traffic, harbour activities and scattered small scale combustion. The percentage of gasoline powered cars in Finland was about $75 \%$ of the total fleet and diesel powered cars had a 25\% share (Mäkelä et al., 2008). $87 \%$ of the fleet were passenger cars. $22 \%$ of all passenger car driven kilometers were diesel powered and $88 \%$ had catalytic converters. Diesel engines have lower emission factors for CO than gasoline engines. Of the total road traffic $\mathrm{CO}$ emissions, diesel engines had a $9.0 \%$ share and gasoline engines $91 \%$ (Mäkelä et al., 2008).

Traffic calculations were made between 27 September and 1 October 2007 in Helsinki at Hämeentie bridge, at about $300 \mathrm{~m}$ distance from our measurement site. The total number of motorized vehicles was about 31000 during a workday and 10500 during a weekend day. During workdays, the percentage of diesel vehicles was $31.3 \%$ of the total fleet, i.e. somewhat higher number than in average in Finland. Estimating from Finland's statistics that gasoline engine $\mathrm{CO}$ emission factors are roughly three times larger than those for
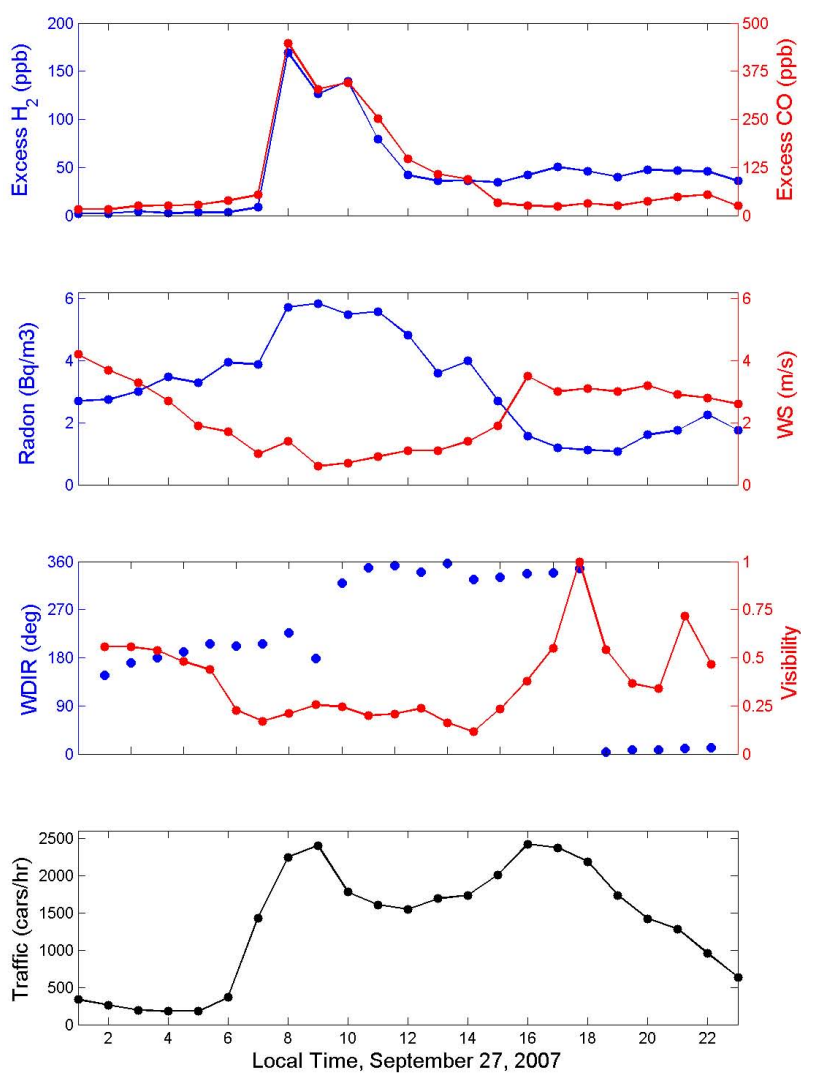

Fig. 9. Excess hydrogen and carbon monoxide mixing ratios, radon activity and weather parameters (wind speed, wind direction, visibility) at Kumpula, site and traffic flow at nearby Hämeentie bridge in 27 September, 2007. Visibility is expressed as fraction of the maximum of the observation range, which is about $50 \mathrm{~km}$. Traffic data provided by Helsinki city traffic office.

diesel engines, a $10 \%$ share is obtained for diesel vehicle CO emissions at Hämeentie (see also Ylituomi et al., 2005).

\subsubsection{Hydrogen emissions due to road traffic}

Hydrogen emissions from traffic can be estimated from the simultaneous increase of hydrogen and $\mathrm{CO}$ during morning rush hours, if carbon monoxide emissions are known, as explained in Sect. 2.4. However, there are a couple of issues to take into consideration while estimating the relevant value for the slope and $\mathrm{CO}$ emissions. Firstly, the $\Delta \mathrm{H}_{2} / \Delta \mathrm{CO}$ slope should be corrected due to soil deposition of $\mathrm{H}_{2}$, which is a significant factor in total $\mathrm{H}_{2}$ budget (Hammer et al., 2009). In Helsinki the $\mathrm{H}_{2}$ deposition velocity was in average about $(3.4 \pm 1.0) \times 10^{-4} \mathrm{~m} / \mathrm{s}$ during September and October 2007 (Lallo et al., 2009) yielding $(1.38 \pm 0.42) \times 10^{-8} \mathrm{~g}$ $\left(\mathrm{H}_{2}\right) \mathrm{m}^{-2} \mathrm{~s}^{-1}$ for the soil sink $\left(j_{\mathrm{H}_{2}}^{\text {soil }}\right)$ in areal basis. The $\mathrm{CO}$ emissions in areal basis ( $j_{\mathrm{CO}}^{\text {emi }}$ in Eq. 2) can be estimated with the help of simultaneous radon observations by using the radon tracer method (Schmidt et al., 2001). $\Delta \mathrm{CO} / \Delta \mathrm{Rn}$ can be estimated similary than $\Delta \mathrm{H}_{2} / \Delta \mathrm{CO}$ by using the rush 
hour measurements of radon and CO. Measurements from 05:00 to 07:00 during 13 days in September and October 2007 were used here. The soil exhalation rate of radon $\left(j_{\mathrm{Rn}}\right)$ needs to be known; the estimate of $43 \mathrm{~Bq} \mathrm{~m}^{-2} \mathrm{~h}^{-1}$ was used for Kumpula (Lallo et al., 2009). Multiplying the radon exhalation rate with the $\Delta \mathrm{CO} / \Delta \mathrm{Rn}$ slope resulted in $(319 \pm 74) \times 10^{-8} \mathrm{~g}(\mathrm{CO}) \mathrm{m}^{-2} \mathrm{~s}^{-1}$ for $j_{\mathrm{CO}}^{\mathrm{emi}}$. Using this result and converting fluxes to molar units, a corrected slope of $0.49 \pm 0.07 \mathrm{ppb}\left(\mathrm{H}_{2}\right) / \mathrm{ppb}(\mathrm{CO})$ was obtained for $\Delta \mathrm{H}_{2} / \Delta \mathrm{CO}$.

Secondly, it has been estimated that hydrogen emissions from diesel engines are very small in comparison to gasoline engines (Vollmer et al., 2007). Therefore the diesel engine $\mathrm{CO}$ emissions (10\%) have to be subtracted from all traffic originated CO-emissions in Helsinki (8285 t (CO)/yr, Niemi et al., 2008) before calculating hydrogen emissions, yielding $7455 \mathrm{t}(\mathrm{CO}) / \mathrm{yr}$ in 2007.

Finally, $\mathrm{H}_{2}$ emissions were estimated using the corrected $\Delta \mathrm{H}_{2} / \Delta \mathrm{CO}$ slope and emissions of $\mathrm{CO}$ from gasoline powered traffic at Hämeentie. The slope of $0.49 \mathrm{ppb}\left(\mathrm{H}_{2}\right) / \mathrm{ppb}(\mathrm{CO})$ corresponds to $0.035 \mathrm{~g} \mathrm{H}_{2} / \mathrm{g} \mathrm{CO}$. Multiplied with $7455 \mathrm{t}(\mathrm{CO}) / \mathrm{yr}$ an estimate of $261 \mathrm{t}\left(\mathrm{H}_{2}\right) / \mathrm{yr}$ was obtained for Helsinki for year 2007. For the whole Finland, using diesel fraction of $9.0 \%$ and road traffic emissions of $208135 \mathrm{t}$ (CO)/yr (Mäkelä et al., 2008), estimated emissions for year 2007 were $6600 \mathrm{t}\left(\mathrm{H}_{2}\right) / \mathrm{yr}$.

\section{Discussion and conclusions}

Hydrogen observations in Helsinki episodically showed high mixing ratios. They usually occurred simultaneously with elevated $\mathrm{CO}$ and coincided with high traffic periods. Despite local pollution by traffic, relatively stable and low background values were often observed at the site, enabling the detection of main features of the $\mathrm{H}_{2}$ seasonal cycle. The slope of $\Delta \mathrm{H}_{2} / \Delta \mathrm{CO}$, calculated during the morning high traffic, also showed seasonal variation with the highest values occurring in summer and lowest in winter. The summer vs. winter variation has been discussed earlier by Hammer et al. (2009), who found more seasonal variation when the late morning hours where included in the slope calculation. They attributed this to the entrainment flux, which amplifies after the sunrise and brings hydrogen rich air from higher altitudes close to the ground, where the stable nocturnal air layer has been depleted with hydrogen over the night due to soil deposition. Due to sunrise at around 04:00-05:00 in June-July at Helsinki, we can assume that there is significant mixing already from the beginning of the morning traffic, which can then affect the slope calculation. Seasonal variation in photochemistry of $\mathrm{CO}$ and $\mathrm{H}_{2}$ and possible minor sources of hydrogen (e.g. seawater microbial activity) should maybe also be considered here. On the other hand, during winter the $\mathrm{H}_{2}$ soil deposition rate was about half of the summer values (Lallo et al., 2009) depleting less $\mathrm{H}_{2}$ from the air. In winter the boundary layer development starts later and is not as strong as in summer due to less heating by radiation. However, surface temperature inversions may occur, trapping the pollutants below the observation height and causing delay and mixing of the observed air parcels. The diurnal variations of $\mathrm{H}_{2}, \mathrm{CO}$, radon and traffic were most consistent during autumn and spring, suggesting that the slopes obtained during these seasons were most reliable.

The $\Delta \mathrm{H}_{2} / \Delta \mathrm{CO}$ slope of $0.43 \mathrm{ppb}\left(\mathrm{H}_{2}\right) / \mathrm{ppb}(\mathrm{CO})$ according to the current work fits nicely to the range of literature estimates presented in recent years. E.g. Hammer et al. (2009) and Barnes et al. (2003) both estimated $0.4 \mathrm{ppb}\left(\mathrm{H}_{2}\right) / \mathrm{ppb}(\mathrm{CO})$ for sites, which were influenced by traffic pollution. Steinbacher et al. (2007) and Yver et al. (2009) both presented $0.33 \mathrm{ppb}\left(\mathrm{H}_{2}\right) / \mathrm{ppb}(\mathrm{CO})$ for suburban sites. Simmonds et al. (2000) obtained only $0.15 \mathrm{ppb}\left(\mathrm{H}_{2}\right) / \mathrm{ppb}(\mathrm{CO})$ for a relatively unpolluted site. However, Novelli et al. (1999) estimated a higher value of $0.6 \mathrm{ppb}\left(\mathrm{H}_{2}\right) / \mathrm{ppb}(\mathrm{CO})$ for a busy traffic intersection. As discussed earlier (Hammer et al., 2009), the shift to lower values might be attributed to hydrogen soil deposition which depletes hydrogen from the air masses on their way to observation sites further away from pollution sources. After correction due to $\mathrm{H}_{2}$ soil deposition in the current work, a value of $0.49 \mathrm{ppb}\left(\mathrm{H}_{2}\right) / \mathrm{ppb}(\mathrm{CO})$ was obtained, which is close to $0.47 \mathrm{ppb}\left(\mathrm{H}_{2}\right) / \mathrm{ppb}$ (CO) by Hammer et al. (2009) and $0.47 \mathrm{ppb}\left(\mathrm{H}_{2}\right) / \mathrm{ppb}(\mathrm{CO})$ by Yver et al. (2009). The result also agrees well with Vollmer et al. (2007), who measured $\mathrm{H}_{2}$ and $\mathrm{CO}$ at a traffic tunnel where the soil deposition term can be neglected. They obtained $0.48 \mathrm{ppb}\left(\mathrm{H}_{2}\right) / \mathrm{ppb}(\mathrm{CO})$ for the mean slope. Their diesel fraction in the car fleet was similar than in average in Finland.

The estimate for $\mathrm{CO}$ emissions owes large uncertainties, because the $\Delta \mathrm{CO} / \Delta \mathrm{Rn}$ slope was not easy to solve by using just a couple of hours close to the sunrise, when $\mathrm{CO}$ increases rapidly and $\mathrm{Rn}$ already starts to saturate before the transition to daytime boundary layer. For comparison, a simulation was made with the 2D atmospheric model (Lallo et al., 2009) for a few typical September weather cases by using the observed $\mathrm{CO}$ increase to obtain the early morning $\mathrm{CO}$ emissions. According to the results, the original emission estimate could be somewhat biased upwards. If we use a lower limit of our error estimate for $\mathrm{CO}$ emissions, $245 \times 10^{-8} \mathrm{~g}(\mathrm{CO}) \mathrm{m}^{-2} \mathrm{~s}^{-1}$, a $\Delta \mathrm{H}_{2} / \Delta \mathrm{CO}$ slope of $0.51 \mathrm{ppb}\left(\mathrm{H}_{2}\right) / \mathrm{ppb}(\mathrm{CO})$ is obtained leading to $<4 \%$ increase in the total $\mathrm{H}_{2}$ emissions. The other sources of uncertainties include e.g. instrumental accuracy and, more importantly, variation in radon exhalation from ground and hydrogen deposition to soil. The last two were estimated in the companion article by Lallo et al. (2009). Together all the uncertainties mentioned above might lead to about $9 \%$ change on the total $\mathrm{H}_{2}$ emissions.

To conclude, our results show, that it is possible to estimate hydrogen emissions in urban environment by using atmospheric tracers such as $\mathrm{CO}$ and radon. The results for $\Delta \mathrm{H}_{2} / \Delta \mathrm{CO}$ slope agreed well with literature values, indicating congruent emission structures. In the future, to place the 
results in a wider context, the hydrogen background levels in Helsinki and in other sites should be examined more carefully including possible transport events and trends.

Acknowledgements. We wish to thank Anu Kousa (YTV Helsinki Metropolitan Area Council) for $\mathrm{CO}$ data and valuable advice concerning CO levels and emissions, Kari Mäkelä (Technical research centre) for Finland traffic and emission statistics and Hannu Seppälä (Helsinki city traffic office) for Hämeentie traffic statistics. This work was financially supported by the Nessling foundation, EU-project EUROHYDROS and Academy of Finland.

Edited by: M. Petters

\section{References}

Barnes, D. H., Wofsy, S. C., Fehlau, B. P., Gottlieb, E. W., Elkins, J. W., Dutton, G. S., and Novelli, P. C.: Hydrogen in the atmosphere: Observations above a forest canopy in a polluted environment, J. Geophys. Res., 108(D6), 4197, doi:10.1029/2001JD001199, 2003.

Derwent, R., Simmonds, P., O’Doherty, S., Manning, A., Collins, W., and Stevenson, D.: Global environmental impacts of the hydrogen economy, Int. J. Nuclear Hydrogen Production and Application, 1, 57-67, 2006.

Ehhalt, D. H. and Rohrer, F.: The tropospheric cycle of H2: a critical review, Tellus, 61B, 500-535, doi:10.1111/j.16000889.2009.00416.x, 2009.

Hammer, S., Vogel, F., Kaul, M., and Levin, I.: The $\mathrm{H}_{2} / \mathrm{CO}$ ratio of emissions from combustion sources: Comparison of top-down with bottom-up measurements in south-west Germany, Tellus, 61B, 556-565, doi:10.1111/j.1600-0889.2009.00418.x., 2009.

Helsinki city traffic office: Traffic volumes on main streets of Helsinki, September 2007, City of Helsinki, City planning office, Traffic planning division report, 5 pp., 2008.

IPCC: Climate Change 2007: The Physical Science Basis. Contribution of Working Group I to the Fourth Assessment Report of the Intergovernmental Panel on Climate Change, edited by: Solomon, S., Qin, D., Manning, M., Chen, Z., Marquis, Z., Averyt, K. B., Tignor, M., and Miller, H. L., Cambridge University Press, Cambridge, United Kingdom and New York, NY, USA, 996 pp., 2007.

Jacobson, M. Z., Colella, W. G., and Golden, D. M.: Cleaning the Air and Improving Health with Hydrogen Fuel-Cell Vehicles, Science, 308, 1901-1905, 2005.

Jacobson, M. Z.: Effects of wind-powered hydrogen fuel cell vehicles on stratospheric ozone and global climate, Geophys. Res. Lett., 35, L19803, doi:10.1029/2008GL035102, 2008.

Jordan, A.: Calibration of atmospheric hydrogen, in: Proceedings of the13th WMO/IAEA Meeting of Experts on Carbon Dioxide Concentration and Related Tracers Measurement Techniques, Boulder, Colorado, USA, 19-22 September 2005, WMO TD No. 1359, 56-63, 2006.

Lallo, M., Aalto, T., Laurila, T., and Hatakka, J.: Seasonal variations in hydrogen deposition to boreal forest soil in Southern Finland, Geophys. Res. Lett., 35, L04402, doi:10.1029/2007GL032357, 2008.

Lallo, M., Aalto, T., Hatakka, J., and Laurila, T.: Hydrogen soil deposition at an urban site in Finland, Atmos. Chem. Phys. Dis- cuss., 9, 14873-14899, 2009,

http://www.atmos-chem-phys-discuss.net/9/14873/2009/.

Mäkelä, K., Laurikko, J., and Kanner, H.: Road traffic exhaust gas emissions in Finland. LIISA 2007 calculation software, Techical Research Centre of Finland (VTT), Report VTT-R-05607-08, 92 pp., 2008.

Niemi, J., Väkevä, O., Kousa, A., Weckström, M., Julkunen, A., Myllynen, M., and Koskentalo, T.: Air Quality in the Helsinki Metropolitan Area in 2007, YTV Helsinki Metropolitan Area Council, Publications 8/2008, 71 pp., 2008.

Novelli, P. C, Lang, P. M., Masarie, K. A., Hurst, D. F., Myers, R., and Elkins, J. W.: Molecular hydrogen in the troposphere: Global distribution and budget, J. Geophys. Res., 104, 3042730444, 1999.

Paatero, J., Hatakka, J., and Viisanen, Y.: Concurrent measurements of airborne radon-222, lead-210 and beryllium-7 at the PallasSodankylä GAW station, Northern Finland, Finnish Meteorological Institute, Air Quality Research, Reports 1998:1, 26 pp., 1998.

Prather, M. J.: An Environmental Experiment with $\mathrm{H}_{2}$ ?, Science, 302, 581-582, 2003.

Price, H., Jaegle, L., Rice, A., Quay, P., Novelli, P. C., and Gammon, R.: Global budget of molecular hydrogen and its deuterium content: Constraints from ground station, cruise, and aircraft observations, J. Geophys Res., 112, D22108, doi:10.1029/2006JD008152, 2007.

Rhee, T. S., Brenninkmeijer, C. A. M., and Röckmann, T.: The overwhelming role of soils in the global atmospheric hydrogen cycle, Atmos. Chem. Phys., 6, 1611-1625, 2006, http://www.atmos-chem-phys.net/6/1611/2006/.

Schmidt, U. and Seiler, W.: A New Method for Recording Molecular Hydrogen in Atmospheric Air, J. Geophys. Res., 75(9), 17131716, 1970.

Schmidt, M., Glatzel-Mattheier, H., Sartorius, H., Worthy, D. E., and Levin, I.: Western European N2O emissions: a top-down approach based on atmospheric observations, J. Geophys. Res., 106, 5507-5516, 2001.

Schmitt, S., Hanselmann, A., Wollschläger, U., Hammer, S., and Levin, I.: Investigation of parameters controlling the soil sink of atmospheric molecular hydrogen, Tellus, 61B, 416-423, 2009.

Schultz, M. G., Diehl, T., Brasseur, G. P., and Zittel, W.: Air Pollution and Climate-Forcing Impacts of a Global Hydrogen Economy, Science, 302, 624-627, 2003.

Service, R. F.: The hydrogen backlash, Science, 305, 958-961, 2004.

Simmonds, P. G., Derwent, R. G., O'Doherty, S., Ryall, D. B., Steele, L. P., Langenfelds, R. L., Salameh, P., Wang, H. J., Dimmer, C. H., and Hudson, L. E.: Continuous high-frequency observations of hydrogen at the Mace Head baseline atmospheric monitoring station over the 1994-1998 period, J. Geophys. Res., 105(D10), 12105-12121, 2000.

Smith-Downey, N. V., Randerson, J. T., and Eiler, J. M.: Temperature and moisture dependence of soil H2 uptake measured in the laboratory, Geophys. Res. Lett., 33, L14813, doi:10.129/2006GL026749, 2006.

Statistics Finland: Greenhouse gas emissions in Finland 19902007, National Inventory Report, 402 pp., 2009.

Steinbacher, M., Fischer, A., Vollmer, M. K., Buchmann, B., Reimann, S., and Hueglin, C.: Perennial observations of molecu- 
lar hydrogen $\mathrm{H}_{2}$ at a suburban site in Switzerland, Atmos. Environ., 41, 2111-2124, doi:10.1016/j.atmosenv.2006.10.075, 2007.

Tromp, T. K., Shia, R.-L., Allen, M., Eiler, J. M., and Yung, Y. L.: Potential Environmental Impact of a Hydrogen Economy on the Stratosphere, Science, 300, 1740-1742, 2003.

Vesala, T., Järvi, L.,, Launiainen, S., Sogachev, A., Rannik, Ü., Mammarella, I., Siivola, E., Keronen, P., Rinne, J., Riikonen, A., and Nikinmaa, E.: Surface-atmosphere interactions over complex urban terrain in Helsinki, Finland, Tellus, 60B, 188-199, 2008.

Vollmer, M. K., Juergens, N., Steinbacher, M., Reimann, S., Weilenmann, M., and Buchmann, B.: Road vehicle emissions of molecular hydrogen (H2) from a tunnel study, Atmos. Environ., 41, 8355-8369, doi:10.1016/j.atmosenv.2007.06.037, 2007.

Warwick, N. J., Bekki, S., Nisbet, E. G., and Pyle, J. A.: Impact of a hydrogen economy on the stratosphere and troposphere studied in a 2-D model, Geophys. Res. Lett., 31, L05107, doi:10.1029/2003GL019224, 2004.
Xiao, X., Prinn, R. G., Simmonds, P. G., Steele, L. P., Novelli, P. C., Huang, J., Langenfelds, R. L., O’Doherty, S., Krummel, P. B., Fraser, P. J., Porter, L. W., Weiss, R. F., Salameh, P., and Wang, R. H. J.: Optimal estimation of the soil uptake rate of molecular hydrogen from the Advanced Global Atmospheric Gases Experiment and other measurements, J. Geophys. Res., 112, D07303, doi:10.1029/2006JD007241, 2007.

Yli-Tuomi, T., Aarnio, P., Pirjola, L., Mäkelä, T., Hillamo, R., and Jantunen, M.: Emissions of fine particles, $\mathrm{NO}_{\mathrm{x}}$, and $\mathrm{CO}$ from on-road vehicles in Finland, Atmos. Environ., 39, 6696-6706, 2005.

Yver, C., Schmidt, M., Bousquet, P., Zahorowski, W., and Ramonet, M.: Estimation of the molecular hydrogen soil uptake and traffic emissions at a suburban site near Paris through hydrogen, carbon monoxide, and radon-222 semicontinuous measurements, J. Geophys. Res., 114, D18304, doi:10.1029/2009JD012122, 2009. 